\title{
MANAJEMEN LABA DAN KONSEKUENSI EKONOMIS (SUATU PENDEKATAN EKSPERIMEN)
}

\author{
Eni Indriani \\ Fakultas Ekonomi dan Bisnis Universitas Mataram \\ eni.indriani@unram.ac.id \\ Rahmi Sri Ramadhani \\ Fakultas Ekonomi dan Bisnis Universitas Mataram \\ rahmisri.ramadhani@unram.ac.id \\ Robith Hudaya \\ Fakultas Ekonomi dan Bisnis Universitas Mataram \\ robith.hudaya@unram.ac.id \\ Tuti Handayani \\ Fakultas Ekonomi dan Bisnis Universitas Mataram \\ tutih93@gmail.com
}

\begin{abstract}
Earnings management can be seen as a discretion allowed by generally accepted Standards, but it also has a less positive impact if earnings that contain certain objectives of the manager (management) become the basis in economic decision making. However, earnings management does not have to be associated with efforts to manipulate accounting data or information, but tends to be associated with choosing accounting methods to manage earnings that can be done because it is permitted by accounting standards. This study is focused on looking at the two sides of earnings management by using an experimental approach and the economic consequences caused by the chosen perspective. The results of data processing indicate that participants' perceptions of ethical and unethical behavior towards earnings management practices are the same as the economic consequences for the organization.
\end{abstract}

Keywords: earnings management, accounting methods, experimental approaches, ethical behavior.

\section{Pendahuluan}

\section{Latar Belakang}

Relevansi nilai informasi akuntansi menjadi isu yang menarik ketika standar akuntansi keuangan konvergen terhadap IFRS (International Financial Reporting Standard). Akan tetapi, ketika perusahaan melakukan praktik manajemen laba, informasi laba tidak lagi dapat menunjukkan kinerja perusahaan sebenarnya, dimana hal ini mengakibatkan reliabilitas 
laba berkurang. Relevansi laba dan nilai buku sebagai alat pengukur kinerja perusahaan menjadi bermasalah ketika dihadapkan dengan praktek manajemen laba (earnings management) yang dipraktikkan oleh manajer. Dilain pihak, manajemen laba sulit untuk dihindari, karena fenomena tersebut merupakan dampak dari penggunaan dasar akrual. Akuntansi yang dicatat dengan basis akrual (accrual basis) merupakan subjek managerial discretion, dimana menurut Watts dan Zimmerman (1986) fleksibilitas yang diberikan oleh GAAP memberikan dorongan kepada manajer untuk memodifikasi laporan keuangan agar dapat menghasilkan laporan laba seperti yang diinginkan, meskipun menciptakan distorsi dalam pelaporan laba.

Motivasi manajer dalam melakukan manajemen laba ada dua, yaitu oportunistik dan signaling. Teori keagenan menjelaskan bahwa manajer melakukan manajemen laba dengan cara menaikkan laba guna memanipulasi kinerja buruk dan melakukan manajemen laba dengan menurunkan laba untuk menunda kinerja baik. Sedangkan, Teori signaling menjelaskan bahwa manajer melakukan manajemen laba dengan melaporkan kenaikan laba adalah untuk memberikan sinyal bahwa laba pada masa yang akan datang akan lebih baik daripada kinerja yang diimplikasikan oleh laba nondiskresioner kini, dan melakukan manajemen laba dengan cara menurunkan laba untuk memberikan sinyal bahwa laba mendatang akan lebih buruk daripada kinerja yang diimplikasikan oleh laba non-diskresioner kini.

Manajemen laba berada pada zona abu-abu, sebagaimana dinyatakan oleh Ronen dan Yaari (2008) sebagai pilihan perlakuan akuntansi baik yang oportunistik untuk memaksimalkan utilitas manajemen maupun untuk tujuan yang efisien secara ekonomi. Menurut Gumanti (2000) Manajemen laba menjadi menarik untuk diteliti karena dapat memberikan gambaran akan perilaku manajer dalam melaporkan kegiatan usahanya pada suatu periode tertentu, yaitu adanya kemungkinan munculnya motivasi tertentu yang mendorong mereka untuk mengatur data keuangan yang dilaporkan. Perlu dicatat disini bahwa manajemen laba tidak harus dikaitkan dengan upaya untuk memanipulasi data atau informasi akuntansi, tetapi lebih condong dikaitkan dengan pemilihan metode akuntansi (accounting methods) untuk mengatur keuntungan yang bisa dilakukan karena memang diperkenankan menurut accounting regulations.

Pandangan terhadap manajemen laba layak untuk diperdebatkan, karena dapat dilihat sebagai suatu keleluasaan yang diperbolehkan oleh Standar yang berterima umum, namun juga memiliki dampak yang kurang positif apabila laba yang mengandung tujuan tertentu dari pengelola (manajemen laba) menjadi dasar dalam pengambilan keputusan ekonomis. Penelitian ini difokuskan untuk melihat dua sisi manajemen laba dengan menggunakan pendekatan eksperimental dan konsekuensi ekonomis yang ditimbulkan oleh sudut pandang yang dipilih.

\section{Rumusan Masalah}

Teori keagenan menjelaskan bahwa manajer melakukan manajemen laba dengan cara menaikkan laba guna memanipulasi kinerja buruk dan melakukan manajemen laba dengan menurunkan laba untuk menunda kinerja baik. Berdasarkan uraian latar belakang di atas dan 
kajian teori tersebut, maka dapat dirumuskan pertanyaan penelitian sebagai berikut : bagaimana persepsi etis terhadap perilaku manajemen laba dari sisi positif dan negatif dan bagaimana konsekuensi ekonomisnya dari sudut pandang yang dipilih?

\section{Tujuan Penelitian}

Berdasarkan latar belakang masalah yang diangkat maka tujuan dari penelitian ini adalah untuk mengetahui persepsi etis dan tidak etis terhadap perilaku manajemen laba dari sisi positif dan negatif dan konsekuensi ekonomisnya dari sudut pandang yang dipilih.

\section{TELAAH LITERATUR DAN PENGEMBANGAN HIPOTESIS}

\section{Tinjauan Teoritis}

Persepsi terhadap manajemen laba dapat ditinjau dari berbagai perspektif dan sudut pandang, Dechow dan Skinner (2000) membahas fakta bahwa akademisi akuntansi seringkali memiliki persepsi terhadap manajemen laba yang sangat berbeda daripada praktisi dan regulator. Praktisi dan regulator sering melihat manajemen laba sebagai sesuatu yang pervasif dan bermasalah dan membutuhkan tindakan pengendalian segera. Akademisi lebih optimis, bahwa walaupun manajemen laba masih aktif dipraktekkan oleh sebagian besar perusahaan, namun yakin bahwa manajemen laba yang dipraktikkan harus selalu memperhitungkan kepentingan investor. Riset ini mengeksplorasi alasan perbedaan persepsi, dan menyimpulkan bahwa masing-masing kelompok ini dapat mengambil manfaat dari perbedaan pandangan mereka tentang pengelolaan laba.

Penelitian Lasdi (2012) tentang evaluasi dan reaksi manajer terhadap skenario manajemen laba yang masih abu-abu dari Ronen dan Yaari (2008), yaitu ketika manajer membuat keputusan apakah terlibat atau tidak dalam perilaku manajemen laba oportunistik dengan konsekuensi yang menguntungkan atau tidak bagi organisasi. Hasil penelitian memberikan bukti bahwa secara umum sifat etis suatu tindakan mempunyai pengaruh terbesar pada judgment etis dan intensi untuk mengintervensi manajer. Akan tetapi, kombinasi perlakuan dari keputusan untuk mengelola laba dengan konsekuensi yang menguntungkan bagi organisasi mendorong pengurangan teguran. Intensi atau keinginan manajer untuk mengintervensi sangat jelas dipengaruhi oleh konsekuensi yang menguntungkan bagi organisasi.

Riset Mubarok dan Utami (2012) tentang persepsi profesi akuntan terhadap penerapan manajemen laba, berakar pada pandangan bahwa profesi akuntan (dosen, akuntan manajemen dan mahasiswa) memiliki persepsi negatif terhadap penerapan manajemen laba. Dari ketiga profesi akuntan, profesi dosen memiliki persepsi yang paling baik $(84,92 \%)$ dibanding profesi akuntan manajemen dan mahasiswa. Penelitian ini juga 
menemukan bahwa ada perbedaan persepsi tentang penerapan manajemen laba antara dosen dengan akuntan manajemen dan dosen dengan mahasiswa, sedangkan untuk profesi akuntan manajemen dengan mahasiswa tidak ditemukan adanya perbedaan persepsi. Meskipun demikian untuk ketiga kelompok profesi akuntan tersebut tidak ditemukan adanya perbedaan rata-rata yang signifikan tentang persepsi penerapan manajemen laba.

\section{Manajemen Laba (Earning Management)}

Manajemen laba merupakan fenomena yang seringkali menjadi sorotan dalam dunia investasi di pasar modal. Menurut Sulistyanto (2008), secara umum manajemen laba didefinisikan sebagai upaya manajer perusahaan untuk mengintervensi atau mempengaruhi informasi-informasi dalam laporan keuangan dengan tujuan untuk mengelabui stakeholderyang ingin mengetahui kinerja perusahaan. Whelan dan McNamara (2004) menyatakan bahwa manajemen laba dapat digunakan sebagai indikator dari reliabilitas laba. Oleh karena itu, jika informasi keuangan perusahaan terindikasi mengandung manajemen laba, maka informasi tersebut tidak dapat diandalkan sebagai dasar pengambilan keputusan investasi.

Motivasi manajer dalam melakukan manajemen laba ada dua, yaitu oportunistik dan signaling. Teori keagenan menjelaskan bahwa manajer melakukan manajemen laba dengan cara menaikkan laba guna memanipulasi kinerja buruk dan melakukan manajemen laba dengan menurunkan laba untuk menunda kinerja baik. Sedangkan, Teori signaling menjelaskan bahwa manajer melakukan manajemen laba dengan melaporkan kenaikan laba adalah untuk memberikan sinyal bahwa laba pada masa yang akan datang akan lebih baik daripada kinerja yang diimplikasikan oleh laba nondiskresioner kini, dan melakukan manajemen laba dengan cara menurunkan laba untuk memberikan sinyal bahwa laba mendatang akan lebih buruk daripada kinerja yang diimplikasikan oleh laba non-diskresioner kini.

\section{Manajemen Laba, Konsekuensi, dan Konsensus Sosial}

Fokus dari kebanyakan penelitian manajemen laba secara relatif pada etika atau moralitas keputusan untuk mengelola laba. Akan tetapi, konsekuensi manajemen laba lebih penting bagi perilaku etis dan corporate governance. Hunt dan Vitell (1986) menyatakan bahwa kebenaran atau kesalahan yang melekat pada perilaku, seperti yang ditetapkan oleh norma sosial atau moral, mempengaruhi pengambilan keputusan etis. Oleh karena itu, seorang individu akan menganggap suatu tindakan sebagai lebih etis ketika menghasilkan konsekuensi positif daripada tindakan yang menghasilkan konsekuensi negatif. Menurut Jones (1991), komponen penting dari keputusan etis adalah intensitas moral yang mendasari tindakan, atau derajat sampai sejauh mana perilaku tersebut dipersepsikan mempunyai karakteristik moral atau etis. Isu sifat kontingen dari manajemen laba dalam organisasi menekankan pentingnya intensitas moral dalam pemahaman etika yang mendasari aktivitas manajemen laba. Jones (1991) menyatakan bahwa Intensitas moral merupakan karakteristik 
pembuat keputusan, dan meliputi enam dimensi: (1) magnituda konsekuensi; (2) konsensus sosial; (3) probabilitas pengaruh; (4) temporal immediacy, (5) proximity, (6) konsentrasi pengaruh. Peningkatan dalam setiap dimensi tersebut menyebabkan peningkatan intensitas moral.

\section{Judgment Etis dan Manajemen Laba}

Perilaku manajemen laba yang dipraktikkan manajemen suatu organisasi menimbulkan konsekuensi tertentu dari stakeholder yang terhubung dengan organisasi. Johnson et al. (2011) menyatakan bahwa evaluasi etis perilaku manajemen laba cenderung merefleksikan (1) konsensus rujukan kelompok (peer) terkait apakah perilaku tersebut etis dan (2) kemungkinan dampak keuangan dari perilaku tersebut pada organisasi. Hal ini menunjukkan hubungan positif antara perilaku manajemen laba, konsekuensinya, dan judgment etis.

Hasil riset dari Rest (1986), Hunt dan Vittel (1986), dan Jones (1991) menemukan bahwa perilaku manajemen laba yang sesuai dengan konsensus sosial dari tindakan etis, dan konsekuensi organisasi yang dipersepsikan positif, akan menghasilkan judgment bahwa perilaku dan konsekuensinya lebih etis. Sebaliknya, perilaku manajemen laba yang berlawanan dengan konsensus sosial etikalitas, dan konsekuensi bagi organisasi yang dirasakan tidak menguntungkan, akan menghasilkan judgment etis bahwa perilaku tersebut dan konsekuensinya lebih kritis.

\section{METODE PENELITIAN}

\section{Rancangan Penelitian}

Penelitian ini bertujuan untuk mengetahui persepsi etis dan tidak etis terhadap perilaku manajemen laba dari sisi positif dan negatif dan konsekuensi ekonomisnya dari sudut pandang yang dipilih. Riset menggunakan desain eksperimen 2x2 factorial multivariate analysis of variance (MANOVA) between-subjects. Pendekatan eksperimen didesain dengan kondisi konsekeuensi organisasi menguntungkan atau tidak menguntungkan tanpa manajemen laba dan dengan manajemen laba, dimana partisipan hanya menerima salah satu dari empat kondisi yang ada. Kondisi Perlakuan Eksperimen antara Kondisi Manajemen Laba dan Konsekuensi Organisasi.

\section{Pemilihan Subjek Partisipan}

Partisipan dalam riset ini berasal dari mahasiswa Magister Akuntansi (Maksi) Fakultas Ekonomi Universitas Mataram. Pertimbangan dalam memilih subyek tersebut adalah untuk dapat mewakili proksi pengambil keputusan yang sebenarnya. Hal ini dikarenakan sebagian besar mahasiswa Maksi telah bekerja dan berpengalaman menjadi pengambil keputusan dalam suatu Organisasi/perusahaan. Sebelum eksperimen dilakukan pada 
subjek yang sesungguhnya terlebih dahulu dilakukan pilot test kepada mahasiswa S1 Jurusan Akuntansi Fakultas Ekonomi Universitas Mataram yang telah menempuh mata kuliah Seminar Akuntansi Keuangan. Pilot test bertujuan untuk mengetahui apakah kasus yang diberikan dapat dipahamai atau tidak oleh partisipan.

Partisipan dikelompokkan dalam empat kondisi perlakuan, masing-masing partisipan mendapatkan satu kondisi treatment. Pemberian tugas eksperimen dilakukan secara acak (randomly assigned) ke dalam kelompok-kelompok (kondisi perilaku etis dan tidak etis, serta kosekuensi ekonomi menguntungkan dan tidak menguntungkan) diperlukan untuk membuat kelompok-kelompok itu dapat dibandingkan dengan variabel dependen (Cooper dan Schinedler, 2001).

\section{Materi Eksperimen}

Penelitian ini menggunakan instrumen skenario yang telah dikembangkan oleh Johnson et al. (2011). Johnson et al. (2011) membangun skenario yang menggambarkan manajemen laba pada area abu-abu atau ambigu dalam organisasi bisnis. Skenario didasarkan pada deskripsi peristiwa perusahaan sesungguhnya yang digunakan oleh Jensen (2003), dan melibatkan karyawan tingkat menengah dengan kesempatan untuk memanipulasi waktu dari peristiwa yang terkat pendapatan dan beban untuk mendapatkan keuntungan personal. Skenario telah dikaji oleh pakar di bidang akuntansi manajemen dan etika bisnis untuk keakuratan dan konsistensi internal.

\section{Metode Analisis Data}

Hipotesis akan diuji dengan menggunakan alat statistik Multivariate ANOVA. Pengujian ini bertujuan untuk memastikan bahwa semua asumsi MANOVA terpenuhi, yaitu memastikan bahwa keseluruhan sampel memiliki varians yang sama. Prosedur analisis data merupakan serangkaian kegiatan yang dilakukan yang terdiri dari : 1) deskripsi statistik atas responden; 2) deskripsi statistik hasil uji materi eksperimen; 3) uji normalitas data; 4) uji dampak antar subyek; 5) kesimpulan.

\section{HASIL PENELITIAN DAN PEMBAHASAN}

\section{Deskripsi Partisipan}

Penelitian ini bertujuan untuk mengetahui persepsi etis terhadap perilaku manajemen laba dari sisi positif dan negatif dan konsekuensi ekonomisnya dari sudut pandang yang dipilih. Sebelum melakukan eksperimen pada partisipan penelitian sebenarnya, tim terlebih dahulu melakukan pilot tes. Pilot tes dilakukan pada mahasiswa S1 Prodi Akuntansi Fakultas Ekonomi dan Bisnis Universitas Mataram yang telah menempuh mata kuliah SAK yang berjumlah 30 orang. Tes ini bertujuan untuk melihat apakah materi eksperimen yang terdiri dari 
empat (4) skenario perilaku Etis dan Tidak Etis, Konsekuensi Organisasi Menguntungkan dan tidak menguntungkan, dapat dipahami oleh partisipan dan adakah dari materi yang perlu direvisi. Pilot tes menunjukkan bahwa partisipan dapat memahami materi eksperimen dengan baik, walaupun ada beberapa pernyataan yang kemudian direvisi berdasarkan hasil tes ini. Mahasiswa Magister Akuntansi (Maksi) yang turut berpatisipasi pada eksperimen ini sebanyak 18 orang yang terdiri dari 10 orang laki-laki berusia antara 24- 48 tahun, dan 8 orang perempuan berusia 23-34 tahun. Adapun jenis pekerjaan yang digeluti oleh partisipan bervariasi, mulai dari Aparatur Sipil Negara, karyawan swasta, wiraswasta, dan mahasiswa murni.

\section{Deskripsi Satistik}

Materi eksperimen berisi empat (4) skenario dari perilaku etis dan perilaku tidak etis, serta konsekuensi ekonomis organisasi yang menguntungkan dan yang tidak menguntungkan. Setelah memilih salah satu dari empat skenario, partisipan kemudian memberikan penialian etika yang terdiri dari penilaian, wajar - tidak wajar; adil - tidak adil; secara moral benar - secara moral tidak benar; dan penerimaan keluarga - keluarga tidak menerima. Hasil penilaian partisipan diuraikan secara statistik dalam tabel berikut:

Tabel 4.1. Deskripsi Statistik Penilaian Partisipan

\begin{tabular}{|c|r|r|r|}
\hline PERILAKU ETIS & \multicolumn{1}{|c|}{ Mean } & Std. Deviation & \multicolumn{1}{l|}{$\mathrm{N}$} \\
\hline 1,00 & 4,3200 & 1,28193 & 25 \\
2,00 & 3,6000 & 2,19848 & 25 \\
3,00 & 2,7600 & 2,35018 & 25 \\
4,00 & 3,8000 & 2,14476 & 15 \\
Total & 3,6000 & 2,07608 & 90 \\
\hline
\end{tabular}

Sumber: Hasil Olah Data Primer (2018)

Berdasarkan informasi pada tabel di atas, dapat diketahui bahwa rata-rata penilaian untuk skenario 1 tentang perilaku tidak etis/konsekuensi yang menguntungkan adalah sebesar 4,32, yang bermakna bahwa penilaian partisipan berada diangka moderat, dengan kata lain partisipan menilai kewajaran perilaku ini berada diangka tengah penilaian atau memilih bersikap netral karena walaupun tergolong tidak etis namun memberikan konsekuensi ekonomis yang menguntungkan bagi organisasi. Skenario 2 yang berisi skenario tidak menguntungkan/konsekuensi yang tidak menguntungkan, diberi penilaian rata-rata sebesar 3,6 sebagai penilaian adil, dimana angka ini mendekati nilai 1 yang berarti bahwa partisipan ratarata menganggap bahwa skenario ini adil bagi kedua belah pihak walaupun tidak ada yang diuntungkan. Skenario 3 tentang perilaku etis/konsekuensi menguntungkan memiliki rata-rata penilaian sebesar 2,76 yang berarti bahwa responden menilai perilaku dan konsekuensinya secara moral benar. 
Skenario 4 mengenai perilaku etis/konsekuensi yang tidak menguntungkan rata-rata dinilai responden sebesar 3,8 yang berarti bahwa selama perilaku memenuhi standar etis walaupun tidak memberi keuntungan, namun dalam konsep keluarga menerima perilaku etis tersebut.

\section{Uji Normalitas Data}

Uji normalitas bertujuan untuk menguji apakah dalam model variabel pengganggu atau residual memiliki distribusi normal. Metode yang handal untuk melihat normalitas data adalah dengan melihat grafik normal probability plot yang membandingkan distribusi kumulatif dari data sesungguhnya dengan distribusi kumulatif dari distribusi normal. Hasil olah data pada tampilan Grafik normal probability plot (lampiran 3) menunjukkan bahwa sebaran data mengikuti arah garis diagonal yang berarti bahwa variasi data memenuhi asumsi normalitas.

\section{Uji Dampak antar Subyek}

Uji dampak antar subjek menggambarkan pengaruh keseluruhan dari eksperimen diuraikan pada tabel di bawah ini:

Tabel Hasil Uji Dampak Antar Subjek

\begin{tabular}{|l|r|l|r|r|r|}
\hline \multicolumn{1}{|c|}{ Source } & \multicolumn{1}{|c|}{$\begin{array}{c}\text { Type III Sum of } \\
\text { Squares }\end{array}$} & df & Mean Square & F & Sig. \\
\hline Corrected Model & $31,200^{2}$ & 3 & 10,400 & 2,538 &, 062 \\
Intercept & 1123,234 & 1 & 1123,234 & 274,115 &, 000 \\
PERILAKU & 31,200 & 3 & 10,400 & 2,538 &, 062 \\
Error & 352,400 & 86 & 4,098 & & \\
Total & 1550,000 & 90 & & & \\
Corrected Total & 383,600 & 89 & & & \\
\hline
\end{tabular}

Sumber: Hasil Olah Data Primer (2018)

Tabel di atas memberikan informasi bahwa nilai $F$ sebesar 2,538 dengan signifikansi 0,062 (di atas 0,05), yang berarti bahwa persepsi partisipan terhadap perilaku etis dan tidak etis atas praktik manajemen laba adalah sama terhadap konsekuensi ekonomisnya bagi organisasi dari sudut pandang yang dipilih partisipan.

\section{Pembahasan}

Seorang individu akan menganggap suatu tindakan etis ketika memberikan konsekuensi positif daripada tindakan yang menghasilkan konsekuensi negatif. Praktik manajemen laba dalam tataran ini kerap dinilai sebagai suatu perilaku yang tidak etis namun ketika dihadapkan pada konsekuensi menguntungkan dan tidak menguntungkan bagi suatu organisasi akan dipandang berbeda. Menurut Jones (1991), komponen penting dari keputusan etis adalah intensitas moral yang mendasari 
tindakan, atau derajat sampai sejauh mana perilaku tersebut dipersepsikan mempunyai karakteristik moral atau etis.

Hasil uji dampak antar subyek menunjukkan bahwa persepsi partisipan terhadap perilaku etis dan tidak etis atas praktik manajemen laba adalah sama terhadap konsekuensi ekonomisnya bagi organisasi dari sudut pandang yang dipilih partisipan. Hasil riset ini sama dengan riset Lasdi (2012) yang menemukan bahwa secara umum sifat etis suatu tindakan mempunyai pengaruh terbesar pada judgment etis dan intensi untuk mengintervensi manajer, dimana intensi atau keinginan manajer untuk mengintervensi sangat jelas dipengaruhi oleh konsekuensi yang menguntungkan bagi organisasi. Tetapi hasil ini berbeda dengan Rest (1986), Hunt dan Vittel (1986), dan Jones (1991) yang menyatakan bahwa perilaku manajemen laba yang sesuai dengan konsensus sosial dari tindakan etis, dan konsekuensi organisasi yang dipersepsikan positif, akan menghasilkan judgment bahwa perilaku dan konsekuensinya lebih etis. Sebaliknya, perilaku manajemen laba yang berlawanan dengan konsensus sosial etikalitas, dan konsekuensi bagi organisasi yang dirasakan tidak menguntungkan, akan menghasilkan judgment etis bahwa perilaku tersebut dan konsekuensinya lebih kritis.

\section{PENUTUP}

\section{Simpulan}

Etika manajemen laba telah banyak diperdebatkan bahwa manajemen laba yang dilakukan semata-mata untuk meningkatkan tujuan pribadi seperti untuk tujuan evaluasi kinerja yang positif, peningkatan gaji dan bonus, hal ini dipandang tidak etis. Beberapa riset membuktikan bahwa perilaku manajemen laba adalah perilaku yang tidak etis. Hasil uji statistik tentang perilaku tidak etis/konsekuensi yang menguntungkan dinilai partisipan tergolong tidak etis namun memberikan konsekuensi ekonomis yang menguntungkan bagi organisasi. Pada skenario tidak etis/konsekuensi yang tidak menguntungkan, partisipan rata-rata menganggap bahwa skenario ini adil bagi kedua belah pihak walaupun tidak ada yang diuntungkan. Skenario tentang perilaku etis/konsekuensi menguntungkan dinilai bahwa perilaku dan konsekuensinya secara moral benar. Skenario mengenai perilaku etis/konsekuensi yang tidak menguntungkan dari sudut pandang keluarga akan menerima perilaku etis ini walaupun tidak memberi keuntungan bagi organisasi. Sehingga, dapat disimpulkan bahwa persepsi partisipan terhadap perilaku etis dan tidak etis atas praktik manajemen laba adalah sama terhadap konsekuensi ekonomisnya bagi organisasi.

\section{Saran}

Penelitian ini terbatas pada penilaian etika tentang praktik manajemen laba dengan pendekatan eksperimen pada mahasiswa yang 
kesehariannya adalah sebagai pengambil keputusan dibidang pekerjaan yang ditekuni masing-masing. Dan posisi ini tercampur antara penilaian sebagai praktisi yang juga terpengaruh oleh pengalaman akademis yang sedang dijalani. Oleh karena itu untuk melihat dampak secara umum terkait dengan perilaku etis manajemen laba, disarankan bagi peneliti selanjutnya untuk melakukan eksperimen pada manajer dari berbagai perusahaan yang tidak sedang menempuh studi.

\section{DAFTAR PUSTAKA}

Baharuddin dan H Satyanugraha. (2004). Faktor-Faktor yang Mempengaruhi Persepsi Profesi Akuntan terhadap Praktik Earning Magement. Media Riset Akuntansi, Auditing dan Informasi. Vol. 4. No. : $1-22$.

Dechow, Patricia M., dan Douglas J. Skinner. 2000. Earning Managements : Reconciling the Views of Accounting Academics, Practitioners, and Regulators. Accounting Horizons, Vol. 14 No. 2. Juni 2000.

Elias, R. 2002. Determinants of earnings management ethics among accountants. Journal of Business Ethics 40 (1): 33-45.

Gumanti, Tatang Ary, 2000. Earnings Management : Suatu Telaah Pustaka. Jurnal Akuntansi dan Keuangan Vol. 2, No. 2. Nopember 2000.

Hunt, S., dan S. Vitell. 1986. A general theory of marketing ethics. Journal of Macromarketing 6 (1): 5-16.

Jensen, M.C., and W. H. Meckling. 1976. Theory of The Firm: Manajerial Behaviour, Agency Cost, and Ownership Structure. Journal of Financial and Economics, 3, 305-360.

Jones, T. 1991. Ethical decision making by individuals in organizations: An issue contingent model. Academy of Management Review 16 (2): 366395.

Johnson, E., G. M. Fleischman, S. Valentine, dan K. B. Walker. 2011. Manager"s ethical evaluations of earnings management and its consequences. Working Paper. SSRN.

Haryani, Linggar Pratiwi, dan Muchamad Safruddin. 2011. Pengaruh mekanisme Corporate Governance terhadap kinerja : transparansi sebagai variabel intervening. Prosiding Simposium Nasional Akuntansi IV, Aceh, 2011.

Holmstrom, Bengt. 1979. Moral Hazard and Observability. The Bell Journal of Economics. Vol. 10 No. 1. 74-91.

Kaplan, S. 2001. Further evidence on the ethics of managing earnings: An examination of the ethically related judgments of shareholders and non-shareholders. Journal of Accounting and Public Policy 20 (1): 2744.

Lasdi, Lodovicus. (2012). Studi Eksperimen Evaluasi Etis Manajer terhadap Manajemen Laba dan Konsekuensinya. SNA Akuntansi Unikal. 2012. 
Mubarok, Abdulloh dan Yuni Utami. (2012). Persepsi Profesi Akuntan terhada Penerapan Manajemen Laba.

Download. portalgaruda.org/article. php?article $=116975 \&$ val $=5$ 330. Di unduh tanggal 10 Maret 2018.

Rest, J. 1986. Moral Development: Advances in Research and Theory. New York: Praeger.

Ronen, J., and V. Yaari. 2008. Earnings Management: Emerging Insights in Theory, Practice, and Research. New York: Springer.

Seal, Will, 2006. Management Accounting and corporate governance : An institutional interpretation of the agency problem. Management Accounting Research, UK, 2006.

Shleifer, A. and R.W. Vishny. 1997. A Survey of Corporate Governance. Journal of Finance, Vol.52. No.2. June, p.737-783.

Sulistyanto, Sri. 2008. Manajemen Laba : Teori dan Model Empiris. Jakarta : PT. Gramedia Widiasarana Indonesia.

Watts, R., and J.L. Zimmerman. 1990. Positive Accounting Theory. The Accounting Review. Vol 65, No. 1.

Whelan, Catherine J., dan Raymond P. McNamara. 2004. The Impact of Earnings Management on the Value-Relevance of Earnings and Book Value : A Comparison of Short-term and Long-term Discretionary Accruals. JEL Classifications : G12, G14, and $M 41$.

\section{Lampiran 1. Skenario Praktik Manajemen Laba}

\section{Skenario A: [Perilaku tidak etis / Konsekuensi yang menguntungkan]}

Terry Patton, seorang manajer dealer mobil yang Anda awasi, sangat ingin memaksimalkan kompensasi insentifnya yang didasarkan pada laba bersih yang dianggarkan untuk dealer. Terry menerima bonus yang lebih tinggi jika dia mencapai $120 \%$ dari target ini, dan bonus yang lebih rendah jika dia hanya mencapai $80 \%$ dari target ini. Skala antara dua kinerja ekstrem ini tidak linier dan mendorong pencapaian laba bersih lebih dari anggaran (100\%). Terry menghitung bahwa jika dia mempercepat atau menunda pendapatan dan pengeluaran untuk meningkatkan variabilitas dealernya. Penghasilan bersih dari waktu ke waktu ia akan rata-rata menerima pendapatan bonus lebih tinggi daripada jika ia tidak mengelola pendapatan dan pengeluaran. Terry memberitahu teman-temannya di dealer perusahaan lain tentang strategi kompensasi dan mampu meyakinkan para manajer yang sangat mampu untuk bergabung dengan perusahaan Terry karena kompensasi jauh lebih menarik. Hal ini menyebabkan perusahaan Terry secara keseluruhan menjadi lebih terkelola dan $18 \%$ lebih menguntungkan tahun ini.

Skenario B: [Perilaku tidak etis / Konsekuensi yang tidak menguntungkan] 
Terry Patton, seorang manajer dealer mobil yang Anda awasi, sangat ingin memaksimalkan kompensasi insentifnya yang didasarkan pada laba bersih yang dianggarkan untuk dealer. Terry menerima bonus yang lebih tinggi jika dia mencapai $120 \%$ dari target ini, dan bonus yang lebih rendah jika dia hanya mencapai $80 \%$ dari target ini. Skala antara dua kinerja ekstrem ini tidak linier dan mendorong pencapaian laba bersih lebih dari anggaran (100\%). Terry menghitung bahwa jika dia mempercepat atau menunda pendapatan dan pengeluaran untuk meningkatkan variabilitas dari pendapatan bersih dealernya dari waktu ke waktu dia akan rata-rata menerima pendapatan bonus lebih tinggi daripada jika dia tidak mengelola pendapatan dan pengeluaran. Terry memberitahu teman-temannya di dealer lain dari perusahaan yang sama tentang rencananya dan mereka juga terlibat dalam pengelolaan pendapatan dan pengeluaran, yang menyebabkan perusahaan secara keseluruhan mengalami penurunan $18 \%$ dalam profitabilitas untuk tahun ini, yang jika ditemukan, dapat sepenuhnya dikaitkan dengan strategi Terry.

\section{Skenario C [Perilaku etis / Konsekuensi yang menguntungkan]}

Terry Patton, seorang manajer dealer mobil yang Anda awasi, telah mendengar manajer dealer di lokasi lain dalam perusahaan Terry membahas kompensasi insentif mereka yang didasarkan pada laba bersih yang dianggarkan untuk dealer khusus mereka. Manajer ini menerima bonus yang lebih tinggi jika mereka mencapai $120 \%$ dari target ini, dan bonus yang lebih rendah jika mereka hanya mencapai $80 \%$ dari target ini. Skala antara dua kinerja ekstrem ini tidak linier dan mendorong pencapaian laba bersih lebih dari anggaran (100\%). Para manajer ini menghitung bahwa jika mereka mempercepat atau menunda pendapatan dan pengeluaran untuk meningkatkan variabilitas dari pendapatan bersih dealer mereka dari waktu ke waktu, mereka akan, rata-rata, menerima bonus lebih tinggi daripada jika mereka tidak mengelola pendapatan dan pengeluaran. Terry baru-baru ini memunculkan praktik ini pada pertemuan manajer dealer dan mencegah manipulasi ini. Dia memperoleh dukungan dari beberapa manajer tetapi kritik dari orang lain. Selama dua belas bulan berikutnya perusahaan secara keseluruhan adalah $18 \%$ lebih menguntungkan karena para manajer yang berhenti memanipulasi laba bersih dealer mereka berdasarkan rekomendasi Terry.

\section{Skenario D: [Perilaku etis / Konsekuensi yang tidak menguntungkan)}

Terry Patton, seorang manajer dealer mobil yang Anda awasi, telah mendengar manajer dealer lain di lokasi lain dalam perusahaan Terry membahas kompensasi insentif mereka yang didasarkan pada laba bersih yang dianggarkan untuk dealer khusus mereka. Manajer ini menerima 
bonus yang lebih tinggi jika mereka mencapai $120 \%$ dari target ini, dan bonus yang lebih rendah jika mereka hanya mencapai $80 \%$ dari target ini. Skala geser antara dua kinerja ekstrem ini tidak linier dan mendorong pencapaian laba bersih lebih dari anggaran (100\%). Para manajer ini menghitung bahwa jika mereka mempercepat atau menunda pendapatan dan pengeluaran untuk meningkatkan variabilitas laba bersih dealer mereka dari waktu ke waktu, mereka akan, rata-rata, menerima pendapatan bonus lebih tinggi daripada jika mereka tidak mengelola pendapatan dan pengeluaran. Terry baru-baru ini memunculkan praktik ini di manajer dealerbertemu dan mematahkan manipulasi ini. Dia memperoleh dukungan dari beberapa manajer tetapi kritik dari orang lain. Beberapa manajer berbakat sangat kecewa dengan komentar Terry bahwa mereka meninggalkan perusahaan, yang menekan profitabilitas perusahaan secara keseluruhan sebesar $18 \%$ tahun ini.

Penilaian etika: Skala Keadilan Moral (Reidenbach dan

\section{Robin 1990)}

Selanjutnya adalah seperangkat kata sifat yang memungkinkan Anda untuk berbagi keseluruhan keyakinan umum Anda tentang situasi di atas mengenai perilaku Terry Patton. (Silakan beri tanda centang di ruang yang secara akurat mencerminkan pendapat Anda).

\begin{tabular}{|l|l|l|l|l|l|l|l|l|}
\hline & $\mathbf{1}$ & $\mathbf{2}$ & $\mathbf{3}$ & $\mathbf{4}$ & $\mathbf{5}$ & $\mathbf{6}$ & $\mathbf{7}$ & \\
\hline Wajar & & & & & & & & $\begin{array}{l}\text { Tidak } \\
\text { Wajar }\end{array}$ \\
\hline Adil & & & & & & & & Tidak Adil \\
\hline $\begin{array}{l}\text { Secara } \\
\text { Moral } \\
\text { Benar }\end{array}$ & & & & & & & & $\begin{array}{l}\text { Secara } \\
\text { Moral } \\
\text { tidak } \\
\text { Benar }\end{array}$ \\
\hline $\begin{array}{l}\text { Keluarga } \\
\text { Saya } \\
\text { Menerima }\end{array}$ & & & & & & & & $\begin{array}{l}\text { Keluarga } \\
\text { Saya tidak } \\
\text { Menerima }\end{array}$ \\
\hline
\end{tabular}

Lampiran 3. Grafik normal probability plot 


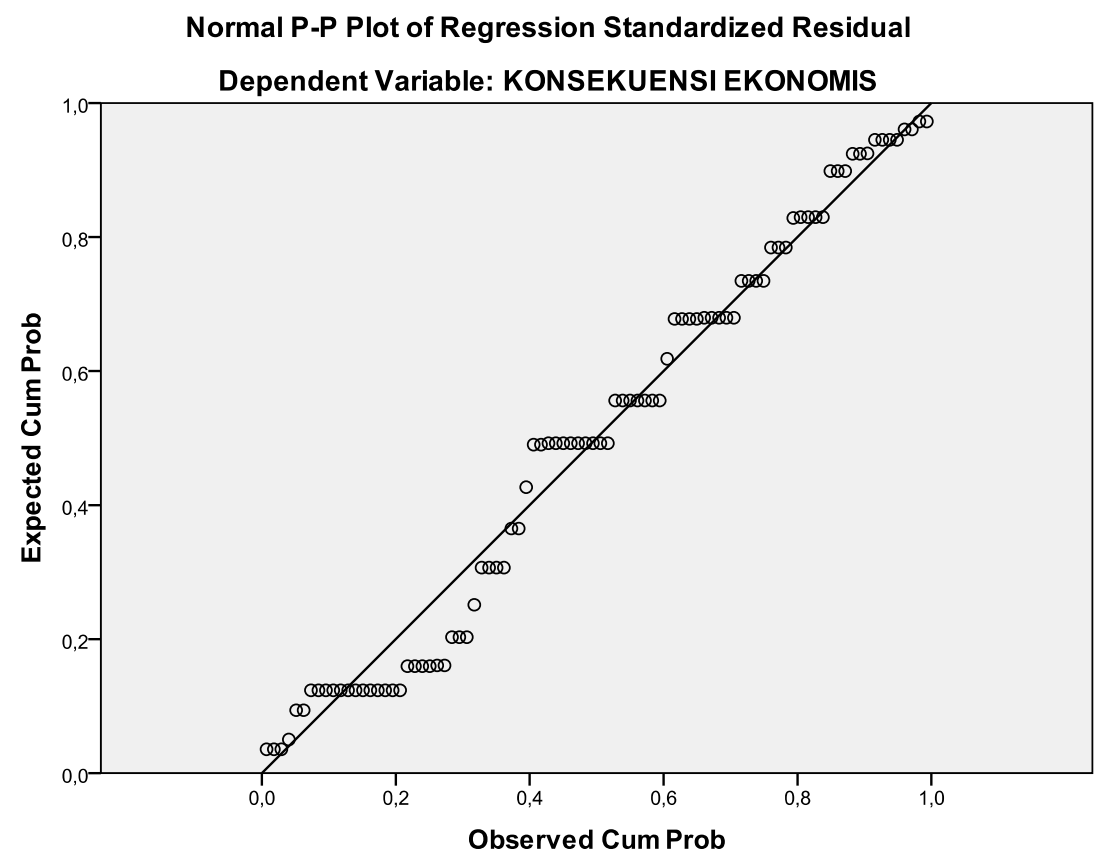

